\title{
Overinvestment, Collateral Lending, and Economic Crisis
}

Yong Jin Kim and Jong-Wha Lee

CID Working Paper No. 4

March 1999

(c) Copyright 1999 Yong Jin Kim, Jong-Wha Lee, and the President and Fellows of Harvard College

\section{Working Papers Center for International Development at Harvard University}




\title{
Overinvestment, Collateral Lending, and Economic Crisis
}

\author{
Yong Jin Kim and Jong-Wha Lee*
}

\begin{abstract}
This paper presents a model in which a high growth economy becomes susceptible to a sudden financial crisis. In the model firms are motivated to over-invest because of government subsidies and then bear the burden of the inefficiencies caused by the government distortion. We assume that the firms compensate for their losses by obtaining bank loans and domestic banks will continuously lend money to the firms as long as the total amount of accumulated loans remain within the limit of the collateral value of real estate. Domestic banks borrow from foreign investors to provide loans for the firms. With these assumptions, we obtain the following results that may well be consistent with the recent experience of East Asian countries. First, a higher growth economy with a higher government subsidy shows higher investment and GDP growth rates, a higher level and growth rate of real estate prices, and a higher level of current account deficits. Second, the rapid growth caused by higher government subsidies makes the economy very vulnerable to adverse shocks. When adverse shocks hit the economy and the expected loanto-collateral value ratio rapidly increases, foreign investors become suspicious about the safety of domestic banks and begin to withdraw their loans. Subsequently, financial panic and economic crisis suddenly occur. Third, capital market liberalization, by provoking huge foreign capital inflows and outflows, increases the possibility of crisis and amplifies the scale of crisis.
\end{abstract}

JEL Codes: E44, F34, O16

Keywords: Economic Growth, Financial Crisis, Industrial Policy, Bank Run, Capital Market Liberalization.

Jong-Wha Lee is a Visiting Scholar at the Center for International Development, an associate professor in Department of Economics at Korea University, and a development associate at the Harvard Institute for International Development.

Yong Jin Kim is an Associate Professor in the Department of Economics at Dongduk Women's University in Korea.

\footnotetext{
"The authors would like to thank Ronald Findlay, Se-Jik Kim, Changyong Rhee and participants at the Korea Econometric Society Macroeconomics Workshop, the $57^{\text {th }}$ Japan Society of International Economics Conference, and the University of Washington at Seattle Conference on the Asian Crisis for helpful comments and suggestions.

Send correspondence to: Jong-Wha Lee, Center for International Development, Harvard University, 79 John F. Kennedy Street, Cambridge, MA 02138. (Tel) 617-496-8712, (Fax) 617-496-8753 (E-mail) jongwha_lee@ harvard.edu
} 


\title{
Overinvestment, Collateral Lending, and Economic Crisis
}

\author{
Yong Jin Kim and Jong-Wha Lee
}

\section{Introduction}

Recently financial crises erupted in the rapidly growing East Asian economies as large-scale foreign capital flowed out of these economies followed by huge depreciation of domestic currencies. The causes of these crises have been the topic of a hot debate not only because East Asian economies had been growing rapidly, serving as a growth model that many developing countries have tried to emulate, but also because their sudden collapse was the least anticipated. Krugman (1998) argues that the Asian crisis is a moral hazard crisis as a consequence of poorly regulated and over guaranteed banks that have recklessly extended credit to risky projects. Radelet and Sachs (1998) regard the crisis in essence as a financial panic triggered by a sudden withdrawal of foreign capital. IMF (1997) attributes the crisis to a combination of factors, including a boom in international lending caused by high growth performance, adverse external shocks, mismanagement of macroeconomic and exchange rate policies, and weak financial sector.

East Asian crises exhibit a complex mixture of currency crisis, banking crisis, and foreign debt crisis, none of which can be singled out as being the sole cause of the crises. Recent empirical studies that have examined a large sample of countries for the determinants of the crises could not come up with a clear answer. ${ }^{1}$ Theoretical models are still very much sought.

In this paper, we present a model that explains some salient features of the East Asian economies. The growth process of the East Asian economies is typically characterized by high investment and economic growth, high real estate prices, current account deficits, and a sudden financial crisis. Until recently, the East Asian economies displayed high saving and investment rates, and rapid GNP growth. Along with these positive signs were a few negative ones such as declines in productivity, increases in current account deficits, and accumulation of corporate debts. Then, suddenly, financial crises swept through these countries. The purpose of this paper is

\footnotetext{
${ }^{1}$ See Kaminsky and Reinhart (1996), Demirguc-Kunt and Detragiache (1997), and Eichengreen and Rose (1997).
} 
to present a model in which a high growth country becomes extremely vulnerable to financial crises.

The model presented in the paper describes an economy in which firms, because of a government subsidy, are motivated to over-invest. We assume that firms pay taxes and thereby bear the burden of the inefficiency caused by the government distortion. In turn, these firms obtain bank loans to compensate for their losses. We also assume that domestic banks borrow from foreign investors to provide funds for the firms. The foreign borrowing will continue to accumulate, as long as domestic banks and foreign investors continue to provide funds for them. One of the critical assumptions of the model is that domestic banks will continue lending money to firms as long as the value of the firms' real estate collateral covers the accumulated loans.

The model shows that a high growth economy caused by a high government subsidy shows a higher price for real estate, higher investment and GDP growth rates, a higher current account deficit, and a higher ratio of debt-to-collateral value. Thus, this model shows that a high growth economy is more likely to be subject to a crisis. It also shows that the underlying financial fragility renders the whole economy extremely vulnerable to adverse shocks. When the adverse shocks hit the economy and foreign investors decide domestic banks are too risky, financial panic and economic crises can suddenly occur. In another words, as soon as foreign investors start to doubt the safety of domestic banks, real estate prices fall to such a level that the market value of real estate can no longer cover the loans which were based on their pre-fall value. As a result, firms and banks become bankrupt. Banking and foreign debt crises suddenly arise. This model also shows that a liberalization of the capital market increases the possibility of crisis and amplifies the scale of crisis due to huge foreign capital inflows and outflows.

The paper is organized as follows. Section 2 describes the basic setup of the model and characterizes its equilibrium. Section 3 derives several implications related to the question previously posed, and Section 4 analyzes the effect of opening financial markets on the economy. Section 5 relates this model to other models of previous studies such as Krugman (1998), Corsetti et al (1998), and Schneider and Tornell (1998), and shows that our model can be interpreted as the moral hazard model. Section 6 presents conclusions. 


\section{The Model}

The economy consists of identical households, firms and banks. The representative agent (household) owns a representative firm through holding shares in the competitive financial markets. The agent consumes one type of commodity and housing service.

The representative firm produces a commodity with an AK type production technology. ${ }^{2}$ The firm owns a house as real estate and uses it as collateral to borrow money from banks. The banks are assumed to lend money to the firm as long as the accumulated loss of the firm remains within the market value of the real estate.

\subsection{Firm's Maximization}

The firm produces an output $Y_{t}$ by employing capital $K_{t}$. We assume that the firm receives a government subsidy $s Y_{t}$ proportional to the firm's output. ${ }^{3}$ The firm bears the burden of a lumpsum tax of $T_{t}$. More generally, this tax represents inefficiencies, proportional to the size of the government subsidy, incurred by the overinvestment in the economy. ${ }^{4}$ These inefficiencies can be caused by the firm's bribes to politicians, and the owner-manager's moral hazard behavior. ${ }^{5}$ Each representative firm owns the fixed $\bar{h}$ units of real estate and rents it to households ${ }^{6}$. Hence, the firm is conducting two businesses- a production business and a real estate business. Or the firm can be considered as a business group (like a Chaebol in South Korea or Keiretsu in Japan) that consists of two subsidiaries.

\footnotetext{
${ }^{2}$ See Barro and Sala-I-Martin (1995, chapter 3).

${ }^{3}$ The government subsidy $s$ is a key parameter in this model. It captures the government policy that induces firms to expand size and thereby distorts resource allocation. The government may impose this subsidy-cum-tax scheme on producers in order to maximize income growth rate (see section 3.1). This subsidy includes various export promoting schemes, such as export financing with lower interest rates, lower tariffs on imports of materials and intermediate goods, providing factory sites at cheaper prices, and so forth.

${ }^{4}$ Some empirical studies support that government industrial policies lead to overinvestment and inefficiency. Lee (1996), for example, shows that, based on the manufacturing industries of Korea, tax incentives increase output growth rates by stimulating capital accumulation, and do not affect total factor productivity (TFP), while nontariff barriers decrease both the output growth rates and TFP. He also shows that financial incentives have no significant effect on either the output growth rates or TFP.

${ }^{5}$ One of the logical linkages between overinvestment and inefficiencies can be attributed to 'crony capitalism'.

${ }^{6} \mathrm{We}$ assume that only firms can hold real estate in order to focus on the problem of bank lending to firms. We further assume, as it is the case in Japan and Korea, that firms are virtually prohibited from earning capital gains from real estate sales due to high tax rates on capital gains. Hence, the fixed patch of land is not considered as a variable controlled by the firms.
} 
The firm knows the current period's productivity of $A_{t}$ in the beginning of each period but cannot observe the next period's productivity $\left(A_{t+1}\right)$. A change in $A_{t}$ can represent a productivity shock, a terms of trade shock, or other shocks affecting the firm's revenue. Then, the representative firm owned by a representative household maximizes its expected discounted profit $^{7}$ with respect to the capital stock $\left(k_{t}\right)$ as

$$
\max E_{t}\left[\sum_{k=0}^{\infty}\left(\prod_{i=1}^{k} \frac{1}{r_{t+i}}\right)\left\{(1+s) A_{t+k} k_{t+k}+q_{t+k} \bar{h}-r_{t+k} k_{t+k}-T_{t+k}\right\}\right.
$$

where $r_{t}$ represents a gross interest rate at time $\mathrm{t}$ greater than one, $q_{t} \bar{h}$ a rental revenue from a household, and $s$ the government subsidy. Here, we assume that capital depreciates by 100 per cent at the end of the period for simplicity. The first order condition with respect to $k_{t}$ yields an equilibrium interest rate as ${ }^{8}$

$$
r_{t}=A_{t}(1+s)
$$

The government balanced budget constraint produces the relationship of

$$
s A_{t} k_{t}=T_{t}
$$

We assume that the firm pays $d_{t}$ a dividend to stockholders and the dividend equals the rental revenue, because the firm's capital that stockholders own is the real estate. ${ }^{9}$

$$
d_{t}=q_{t} \bar{h}
$$

From equations (1), (2), (3) and (4), the firm's profit after dividends will be

\footnotetext{
${ }^{7}$ This profit is an operating profit, which does not include capital gains from holding real estate.

${ }^{8}$ The firm's investment is financed through domestic savings at the domestic equilibrium rate.

${ }^{9}$ In other words, stockholders are being paid the market equilibrium yield for owning the real estate.
} 


$$
\begin{aligned}
\pi_{t} & =-T_{t} \\
& =-s A_{t} k_{t}
\end{aligned}
$$

We assume that the firm will compensate for the loss by borrowing foreign capital from banks. The loss will be accumulated as long as the firm continues to borrow. ${ }^{11}$

\subsection{Household's Maximization}

A representative household lives in the house that she rents from the representative firm. The representative agent living an infinity life maximizes the preference of ${ }^{12}$

$$
\max U=E_{t}\left[\sum_{j=0}^{\infty} \beta^{t+j}\left\{\log \left(c_{t+j}\right)+\theta \cdot \log \left(h_{t+j}\right)\right\}\right]
$$

\footnotetext{
${ }^{10}$ The seemingly unrealistic assumption that the firm making losses provides shareholders with positive dividends as equations (4) and (5) describe can be rationalized by considering one business group which controls two

subsidiaries. A real estate business subsidiary owns houses through equity financing and rents them to households at market rates. The rents are distributed to shareholders. And the other subsidiary, which produces goods, incurs losses but covers them through bank loans. We can assume that the real estate subsidiary guarantees these bank loans for the production subsidiary by using the real estate as collateral. This cross-subsidiary debt guarantee is one of the well-known business practices among Korean Chaebols (see World Bank, 1998). Differently, we can assume that the current production subsidiary goes bankrupt in each period after one period's business due to its losses, and that a new and identical subsidiary doing the same business is established by the business group by borrowing money from the banks using its real estate as collateral. This can rationalize positive dividends of the loss-incurring firm. Another rationalization can be made following the moral hazard story discussed in Section 5.

${ }^{11}$ To simplify the problem, we assume that all economic agents are myopic in the sense that they do not consider the possibility of a financial and economic crisis. This assumption is not very strong because many studies show that the East Asian financial crises were least anticipated. The main results will not change by incorporating the possibility of a crisis. The firm's maximization problem will not change even in the model when we consider the possibility of a crisis. However, the dividend should increase to compensate for the risk of a crisis. Then, the firm's losses also increase. Note also that as long as the foreign investors are willing to lend money with the collateral value covering the debt, all of the agents ignore the firm's losses. This is because shareholders are well compensated for their investment at the market (risk-adjusted) rate and because the investment by domestic banks and foreign investors is safely secured by the collateral (with foreign interest rates raised to cover the risk of a crisis). Owner-managers as well as shareholders may even prefer higher subsidies causing more losses to the firms since such subsidies, although increasing the firm's losses, raise the economic growth rate.

${ }^{12}$ The households do not consider the possibility of crisis, as stated in the above footnote. One of the easiest ways to incorporate the crisis possibility is stated in Footnote 22.
} 
where $E_{t}[\cdot]$ represents an expectation operator conditional on the information set of time t, $c_{t}$ consumption of the commodity at time $t, h_{t}$ consumption of housing service ${ }^{13}$ and $\beta$ a time discount rate.

The agent maximizes her discounted utility with the budget constraint of

$$
c_{t}+q_{t} h_{t}+k_{t+1}=r_{t} k_{t}+d_{t},
$$

where $q_{t}$ denotes the price of one unit of housing service, $k_{t+1}$ saving, $r_{t}$ a gross interest rate on the saving of $k_{t}$ observable at time $\mathrm{t}$ in the competitive financial market, and $d_{t}$ the dividend from the holding shares at time $\mathrm{t}^{14}$. The budget constraint shows that the household does not bear the burden of the tax at all. ${ }^{15}$

Using equations (2) and (4), equation (7) can be transformed as

$$
\begin{aligned}
c_{t}+k_{t+1} & =I_{t} \\
& =(1+s) A_{t} k_{t}
\end{aligned}
$$

where $I_{t}$ represents the household's disposable income after paying rents at time t.

The representative consumer's maximization problem of (6) subject to (7) can be solved by setting up the value function as follows, neglecting the utility from housing service consumption. ${ }^{16}$ Here, time subscripts are omitted and the prime on variables represents 'the next period'.

\footnotetext{
${ }^{13}$ In equilibrium, $h_{t}=\bar{h}$.

${ }^{14}$ The household owns the firm by holding its shares. The profit the household obtains through dividends can not be negative due to its limited liability. To simplify the problem, we assume that the dividend equals the rent $q_{t} h_{t}$.

${ }^{15}$ If the household bears the full burden of the tax, firms will not suffer losses since the tax is completely internalized by the household. However, even in this case, firms can incur some losses due to inefficiencies caused by the overinvestment, as stated before.

${ }^{16}$ To solve the representative consumer's maximization problem, we resort to the Pareto optimal problem solving (6) subject to (8) and $h_{t}=\bar{h}$. Then we can substitute $h_{t}=\bar{h}$ in (6), and can neglect this variable in the value function when solving for the other decision variables of the consumer.
} 


$$
\begin{aligned}
& V((1+s) A k)= \\
& \max _{k^{\prime}} \log \left((1+s) A k-k^{\prime}\right)+\beta \int V\left((1+s) A^{\prime} k^{\prime}\right) d P\left(A^{\prime} \mid A\right)
\end{aligned}
$$

where $P\left(A^{\prime} \mid A\right)$ is the cumulative distribution function of $A^{\prime}$ conditional on the realized value of A.

After positing the value function as

$$
V(I)=a+b \log (I)
$$

we can solve (9) using an envelop theorem and the first order condition (FOC).

First, we obtain the following relationship by applying an envelop theorem to equation (9) and combining it with equation (10) as

$$
\frac{b}{(1+s) A k}=\frac{1}{(1+s) A k-k^{\prime}} \Rightarrow k^{\prime}=\frac{b-1}{b}((1+s) A k)
$$

Additionally, equation (11) and the FOC with respect to $k^{\prime}$ yield

$$
\begin{gathered}
\frac{1}{(1+s) A k-k^{\prime}}=\beta \int \frac{b(1+s) A^{\prime}}{(1+s) A^{\prime} k^{\prime}} d P\left(A^{\prime} \mid A\right) \\
=\beta \int \frac{b^{2}}{(b-1)(1+s) A k} d P\left(A^{\prime} \mid A\right)
\end{gathered}
$$

Equation (12) yields a solution for $b$ as

$$
b=\frac{1}{1-\beta}
$$

Thus, equation (11) produces a solution for $k^{\prime}$ as 


$$
k^{\prime}=\beta(1+s) A k
$$

Also, from equations (8) and (14), we can solve for an optimal consumption decision as

$$
\begin{aligned}
c & =\frac{I}{b} \\
& =(1-\beta)(1+s) A k
\end{aligned}
$$

Note that consumption and investment decisions do not depend on the probability distribution of $A^{\prime}$.

Equations (14) and (15) produce optimal growth rates of consumption and capital stock as

$$
\begin{aligned}
& \frac{k^{\prime}}{k}=\beta(1+s) A \\
& \frac{c^{\prime}}{c}=\beta(1+s) A
\end{aligned}
$$

Equations (15) and (16) show that the household in this economy with a positive government subsidy, s>0, enjoys higher consumption-income ratios and higher consumption growth rates over the period.

Utilizing the properties of a logarithmic utility function, we can solve for the price of one unit of the housing service with a general equilibrium condition $h_{t}=\bar{h}$ as

$$
q_{t}=\frac{\theta c_{t}}{\bar{h}}
$$

\subsection{The Equilibrium}

Equation (16) shows that consumption and capital grow at the rate $\beta(1+s) A_{t}$. Consumption and investment ratios to income stay constant over time, as we can see from equations (11) and (15). 
Equation (8) implies that excess demand for goods over GNP leads to a current account deficit because the tax burden imposed on firms is not internalized in the household's budget constraint. As indicated in equation (8), the household budget exceeds the general equilibrium condition for a commodity market by $s A_{t} k_{t}$, because the economy produces only $A_{t} k_{t}$. However, in an open economy, which we assume here, the excess demand of $s A_{t} k_{t}$ will be financed by the current account deficit. Note that an economy with $s=0$ satisfies the general equilibrium condition with a current account balance (see Table 1 in Appendix).

\subsection{Bank's Behavior}

Assume that domestic banks borrow money from foreign investors and lend it to firms to pay for their losses. Further we assume that the banks will continue lending to the firms as long as the collateral value of real estate covers the accumulated bank loan (the firm's accumulated loss). ${ }^{17}$

We also assume that domestic banks and foreign investors are risk neutral. In other words, they are concerned solely with their expected return. Therefore, if the expected return of loans falls below a certain threshold level, they will stop providing funds for the firms. When the expected ratio of the collateral value to loans falls below a certain threshold level, foreign investors will not continue to lend money to domestic banks. Domestic banks are also assumed to behave as foreign investors do by lending money to the firms until the expected ratio of collateral value to loans falls below the threshold level. ${ }^{18}$

\footnotetext{
${ }^{17}$ This assumption implies that banks are doing business mainly through collateral lending, rather than credit lending based on credit evaluation. This is a well-known business practice adopted by financial institutions in underdeveloped countries.

${ }^{18}$ Even though the foreign investor's threshold level can be much lower than the domestic bank's, we simply assume that these threshold levels are identical. This assumption does not influence the main implication because, as long as the foreigner's threshold level is lower than or equal to the domestic bank's, the crisis depends only on the foreign investor's, not on the domestic bank's. The optimal threshold level can be derived from the bank's profit maximization problem.
} 
Using equations (2), (16) and (17), the price of one unit of real estate will be calculated as

$$
\begin{aligned}
P_{h t} & =E_{t}\left[\sum_{j=0}^{\infty}\left(\prod_{k=1}^{j} \frac{1}{r_{t+k}}\right) q_{t+j}\right] \\
& =E_{t}\left[\sum_{j=0}^{\infty}\left(\prod_{k=1}^{j} \frac{1}{r_{t+k}}\right) \frac{\theta}{\bar{h}} c_{t+j}\right] \\
& =E_{t}\left[\sum_{j=0}^{\infty}\left(\prod_{k=1}^{j} \frac{g_{t+k}}{r_{t+k}}\right) \frac{\theta}{\bar{h}} c_{t}\right] \\
& =\frac{\theta}{\bar{h}} c_{t}(1-\beta)^{-1} \\
& =A_{t} k_{t} \frac{\theta(1+s)}{\bar{h}}
\end{aligned}
$$

where $g_{t}$ represents the gross growth rate of income at time t. Equation (18) says that real estate prices in an overinvesting economy with positive government subsidies $s>0$ are higher and grow faster than in an economy with $s=0$.

Then, the ratio of real estate value to GNP will be

$$
\frac{P_{h t} \bar{h}}{A_{t} k_{t}}=\theta(1+s) .
$$

Equation (19) implies that an increase in $s$ raises this ratio. ${ }^{19}$

Now, recall that domestic banks provide loans for firms by borrowing money from foreign investors as long as the total amount of loans to the firms does not exceed the collateral value of the real estate. To simplify the analysis, we further assume that the lending rate to firms to compensate for their losses is the foreign gross interest rate $r^{f} .^{20}$

\footnotetext{
${ }^{19}$ This partly explains why Korea and Japan show very high values of this ratio. One study shows that Korea has a ratio of 4-5, Japan of 2-3, compared to the U.S. of 0.6.

${ }^{20}$ The result will not change qualitatively when banks are allowed to charge firms a lending rate higher than the foreign rate. We can assume that the domestic lending rate will fall to the level of the foreign rate through competition among banks.
} 
From equation (4), the firm's accumulated bank loan to bear its losses at time t can be calculated to be

$$
\begin{aligned}
L_{t} & =s\left(A_{t} k_{t}+r^{f} A_{t-1} k_{t-1}+r^{f^{2}} A_{t-2} k_{t-2}+\ldots+r^{f^{t}} A_{0} k_{0}\right) \\
& =s A_{t} k_{t}\left(1+\frac{r^{f}}{\beta r_{t}}+\frac{r^{f}}{\beta r_{t}} \frac{r^{f}}{\beta r_{t-1}}+\frac{r^{f}}{\beta r_{t}} \frac{r^{f}}{\beta r_{t-1}} \frac{r^{f}}{\beta r_{t-2}}+\ldots+\frac{r^{f}}{\beta r_{t}} \frac{r^{f}}{\beta r_{t-1}} \ldots \frac{r^{f}}{\beta r_{1}}\right)
\end{aligned}
$$

Equation (20) implies that the total amount of bank loans can remain within the collateral value at any point in time, if the inequality of $\frac{r^{f}}{\beta r_{i}} \leq \varepsilon<1$ holds for each period and for a certain constant $\varepsilon$. In the discussion below, we assume that this inequality holds true. This inequality implies the following. If we define the smallest value in the support of the distribution of $A_{t}$ as $\underline{A}$, then $\varepsilon=\frac{r^{f}}{\beta \underline{A}(1+s)}$ and the inequality $\frac{r^{f}}{\beta r_{i}} \leq \varepsilon<1$ implies that $\frac{r^{f}}{\beta \underline{A}(1+s)}<1$. Thus, the higher the domestic productivity (A) and the subsidy (s) are and the lower the foreign interest rate $\left(\mathrm{r}^{\mathrm{f}}\right)$ is, the more probably this relationship holds.

\subsection{Collateral Lending Condition}

Equations (18) and (20) yield the expected ratio of bank loan to collateral value to be

$$
E_{t}\left[\frac{L_{t+1}}{P_{h t+1} \bar{h}}\right]=E_{t}\left[\frac{s\left(A_{t+1} k_{t+1}+r^{f} A_{t} k_{t}+r^{f^{2}} A_{t-1} k_{t-1}+\ldots+r^{f^{t}} A_{0} k_{0}\right)}{A_{t+1} k_{t+1} \theta(1+s)}\right]
$$

Note that a decrease in the expected $A_{t+1}$ increases this ratio, as we can see from (18) and (20), by lowering the land price more than the accumulated amount of the loan. Thus, for example, a negative shock to terms of trade, which lowers $A_{t+1}$, raises this ratio.

We call the condition of the expected ratio, as expressed by (21), being less than one as the collateral lending condition. ${ }^{21}$ With an additional assumption, to get steady state implications,

\footnotetext{
${ }^{21}$ The condition that the debt to asset value ratio is less than one is commonly used to describe the bank's behavior of collateral lending as in Kiyotaki and Moore [1997] and Schneider and Tornell [1998].
} 
that foreign debt starts from minus infinity time, equations (20) and (21) give the collateral lending condition that makes this ratio less than one at any time and for any realization of $A_{t}$ as

$$
E_{t}\left[\frac{L_{t+1}}{P_{h t+1} \bar{h}}\right] \leq \frac{s}{\theta(1-\varepsilon)(1+s)} \leq 1
$$

We assume that domestic banks will continue to lend money to firms as long as the above collateral lending condition holds. At this point, we further assume that foreign investors will also lend money to domestic banks as long as the collateral lending condition of (22) is satisfied, just as domestic banks will lend to domestic firms.

$$
\text { Substituting } \varepsilon=\frac{r^{f}}{\beta \underline{A}(1+s)} \text { into equation (22), the inequality of (22) can be transformed }
$$

as

$$
\frac{s(1-\theta)}{\theta} \leq \frac{\beta \underline{A}-r^{f}}{\beta \underline{A}}
$$

This inequality can be interpreted differently depending on the value of $\theta$. First, if $\theta$ is greater than or equal to one, then inequality of (23) always holds true only if the foreign rate is lower than $\beta_{\underline{A}}$. In other words, irrespective of any realization of $A_{i}$ the collateral lending condition will be satisfied for any positive value of $s$. Second, if $\theta$ is less than one, and if the foreign rate is lower than $\beta_{\underline{A}}$, then (23) gives the inequality on $s$ as

$$
s \leq \frac{\theta}{1-\theta} \frac{\beta \underline{A}-r^{f}}{\beta \underline{A}} .
$$

This equation implies that if $\theta$ is less than one, the lower the foreign interest rate and the government subsidy are, the more probable the collateral lending condition of (22) holds. In other words, if the government subsidy is too high, then the collateral lending condition will not hold. We consider that this case of $\theta$ less than one is more plausible. Equations (6) and (17) imply that 
the housing rental expenditure is greater than the sum of other consumption expenditures, if $\theta$ is greater than one. This is very unrealistic. Thus, we will focus on the case of $\theta<1$.

\section{Implications}

\subsection{Welfare Maximizing Government Policy}

In this subsection, we will explore the welfare implications of a government subsidy $(s)$.

Equations (15) and (16) imply that an increase in $s$ raises the household consumption in any period $t \geq t_{0}$ given a fixed capital stock of $k_{t_{0}}$. Also, note that the government subsidy $(s)$ should satisfy equation (23). Thus, we can guess that the welfare maximizing government subsidy plan will be to set $s$ to the maximum value of $s$ subject to (23).

Using equations (13) and (15), the expected welfare function (the discounted utility) at time $t$ of a representative agent given the capital stock $k_{t}$ can be described by

$$
\begin{aligned}
\sum_{i=0}^{\infty} \beta^{t+i} E_{t}\left[\log c_{t+i}\right]=\sum_{i=0}^{\infty} \beta^{t+i} E_{t}\left[\log \left(c_{t} \prod_{j=1}^{i} g_{t+i}\right)\right] \\
=\frac{1}{1-\beta} \log c_{t}+\frac{E_{t}\left[\sum_{i=1}^{\infty} \beta^{i} g_{t+i}\right]}{1-\beta} \\
=\frac{1}{1-\beta} \log (1-\beta)(1+s) A_{t} k_{t}+\frac{\sum_{i=1}^{\infty} \beta^{i+1}(1+s) E_{t}\left[A_{t+i}\right]}{1-\beta},
\end{aligned}
$$

where $g_{t}$ represents gross growth rate at time $\mathrm{t}^{22}$

Thus, the optimal policy of $s$ will be determined by solving the maximization problem of (25) subject to (23). Equation (25) implies that an increase in $s$ increases the welfare. In addition, equation (23) implies that, in the realistic case of $\theta<1$, the maximum possible value of $s$ is constrained by (24). Thus, we can easily infer that the maximum value of $s(s *)$ will depend on

\footnotetext{
${ }^{22}$ This welfare function is calculated under the assumptions that foreign investors will continue to lend money to domestic banks, as long as the collateral lending condition is satisfied, and that all agents do not consider the possibility of a crisis. However, we can consider the possibility of bankruptcy caused by the foreign investor's behavior by plugging the parameter of not having bankruptcy $\mathrm{P}$. If we assume that the variable $\mathrm{P}$ is exogenously given and that the utility under bankruptcy is nil, then all we have to do is to substitute $\mathrm{P} \beta$ for $\beta$ in (25).
} 
the value $\theta$. If the cost of violating the collateral lending condition (22) is large enough, then $s^{*}$ will be the government's optimal policy. Thus, a lemma follows:

Lemma 1: If $\theta<1$ and the cost of violating the collateral lending condition is very large, the government's optimal subsidy will be: $s^{*}=\frac{\theta}{1-\theta} \frac{\beta \underline{A}-r^{f}}{\beta \underline{A}}$.

This lemma says that if the government's subsidy to induce a firm's overinvestment is larger than a certain threshold value of $s\left(s \geq \frac{\theta\left(\beta \underline{A}-r^{f}\right)}{(\theta-1) \beta \underline{A}}\right)$, then the collateral lending condition will not hold, if $\theta<1$. In other words, an excessive government subsidy will hurt the economy by incurring a financial crisis. On the contrary, if $\theta>1$, the debt to real estate value ratio decreases in $\mathrm{s}$, because the real estate value increases faster than the accumulated loans to firms as $s$ increases. And, if $\theta$ is equal to one, (23) holds irrespective of the value of s. Therefore, if $\theta \geq 1$, then the government optimal subsidy will be the infinite value of $s$. However, as stated before, this case is not very probable in the real world.

\subsection{Overinvestment, High Growth, and Current Account Deficit}

The following proposition summarizes the results described above.

Proposition 1: An increase in the government subsidy $(s)$, which induces overinvestment in the economy, raises income growth rates, the ratio of consumption to income, welfare, real estate prices, and current account deficits as long as $s \leq \frac{\theta\left(\beta \underline{A}-r^{f}\right)}{(\theta-1) \beta \underline{A}}$ and $\theta<1$. If $\theta \geq 1$, this always holds true for any positive value of $s$, as long as the domestic interest rate is higher than the foreign rate.

(Proof) Refer to Table 1 in Appendix in which an over-investing economy is compared to a normal. 


\subsection{Financial Crisis}

The continuous accumulation of high corporate and foreign debts arising from the collateral lending practices of domestic banks makes this economy very fragile. Whenever the confidence of foreign investors starts to falter, the high debt economy can then collapse easily. As soon as the foreign investors think that the collateral lending conditions will not be likely to hold, they start to recall their loans, which immediately leads to a financial crisis in the country.

Now, we can illustrate the eruption of a financial crisis by the following lemma and propositions.

Lemma 2: In an economy where overinvestment and debt accumulation exist, adverse shocks that lower productivity $(A)$ or raise foreign interest rates $\left(r^{f}\right)$ can increase the expected debt-tocollateral value ratio so that the collateral lending condition of both domestic and foreign banks does not continue to be satisfied. This will be more likely to happen in a higher growth economy with a higher level of government subsidy.

(Proof) In equation (21), a decrease in the expected $A_{t+1}$ or an increase in $r^{f}$ can increase the debt-to-collateral value ratio above one by lowering the land price more than the accumulated amount of the loan. Also, in equations (20) and (22), it is clear that if a permanent adverse shock forces $\frac{r^{f}}{\beta r_{i}}>1$ for each $i>t$, the total expected value of growing loans will exceed the value of real estate collateral in a finite time. The latter part of the proof is obvious from Proposition 1.

When adverse shocks hit the economy and foreign investors expect the ratio of debt-tocollateral value to rise above one, the foreign investors become skeptical about the future safety of the domestic banks. Foreign investors are justified in their misgivings about the safety of domestic banks for several reasons in addition to the fact that the ratio of loan to land value exceeds one. First, the BIS equity-asset ratio of domestic banks will continuously decrease because firms' debts will increase over time. Second, the losses incurred by domestic firms lead to the accumulation of non-performing loans in domestic banks. Third, due to continuous current account deficits, the economy is highly vulnerable to a foreign currency liquidity crisis. 
As a result, this country with an over-investment policy can easily become a hostage to a foreign debt and banking crisis. The following proposition summarizes these results.

Proposition 2: Negative shocks such as negative terms-of-trade shocks can push a higher growth country with higher government subsidies into a financial crisis by raising the debt-to-collateral value ratio above one.

Additionally, this economic crisis possesses a feature of the self-fulfilling prophecy of the bank run model of Diamond and Dybvig (1983). In other words, if foreign investors start to regard domestic banks as risky (even if the ratio of debt-to-collateral value is slightly less than one), then it will surely become risky, because the gloomy prospect among foreign investors raises this ratio above one. To explain this feature, we introduce two more equations below.

Using (16), equation (21) can be transformed into

$$
E_{t}\left[\frac{L_{t+1}}{P_{h t+1} \bar{h}}\right]=E_{t}\left[\frac{s\left(A_{t+1} k_{t+1}+r^{f} A_{t} k_{t}+r^{f^{2}} A_{t-1} k_{t-1}+\ldots+r^{f^{t}} A_{0} k_{0}\right)}{A_{t+1} A_{t} k_{t} \beta \theta(1+s)^{2}}\right] .
$$

If each foreign investor expects that all other foreign investors will not lend money to the domestic banks, the collateral value will fall. The reasoning is as follows. If economic agents realize that borrowing cannot continue due to the behavior of foreign investors, then they will infer that the economy will shift to an economy with $s=0$. In this case, (18) implies that real estate prices will fall with $s=0$. Since the high growth of the economy can not be sustained without foreign borrowing, economic agents assume that the future expected rents will drop and then the real estate price, the expected summation of future rent flows, will fall. During this period with a given amount of the firm's bank loan, the collateral lending condition (22) with a proper inequality may not be satisfied. When the condition is not satisfied, firms and banks go bankrupt.

Thus, considering that government subsidy is forced to discontinue as foreign investors stop lending, the expected debt-to-collateral value ratio rises as below. 


$$
E_{t}\left[\frac{L_{t+1}}{P_{h t+1} \bar{h}}\right]=E_{t}\left[\frac{S\left(A_{t+1} k_{t+1}+r^{f} A_{t} k_{t}+r^{f^{2}} A_{t-1} k_{t-1}+\ldots+r^{t^{t}} A_{0} k_{0}\right)}{A_{t+1} A_{t} k_{t} \beta \theta}\right] .
$$

From equations (26) and (27), we can derive an additional proposition related to a selffulfilling prophecy.

Proposition 3: If $\frac{1}{(1+s)^{2}}<E_{t}\left[\frac{L_{t+1}}{P_{h t+1} \bar{h}}\right]<1$ with $s$ positive valued, then merely the belief of a bad prospect in the domestic economic condition among foreign investors can push the economy with a positive $s$ into a lower growth economy with $s=0$. It can also trigger bankruptcies of banks and firms in the country.

(Proof) Comparing (26) with (27), we can infer that a foreign investor will not invest when the other investors do not invest, because she expects the collateral lending condition will no longer be satisfied. In other words, if a country's debt is in such a risky position as $\left(\frac{1}{(1+s)^{2}}<E_{t}\left[\frac{L_{t+1}}{P_{h t+1} \bar{h}}\right]<1\right)$ and if some foreign investors stop lending money to domestic banks, then other foreign investors will also stop lending. The mechanism of this investors' herd behavior is identical to that of the bank run model of Diamond and Dybvig (1983). Specifically, for an individual foreign investor, it is a Nash equilibrium to stop lending money, when other investors stop lending. If the investor continues lending money to domestic banks whereas others do not, then she suffers losses. This is because the collateral value cannot cover the total value of debt and thereby domestic firms and banks go bankrupt, as we can see from equations (26) and (27) under the condition that $\frac{1}{(1+s)^{2}}<E_{t}\left[\frac{L_{t+1}}{P_{h t+1} \bar{h}}\right]<1$. So, the proof of the second part of the proposition is followed by the fact that if the debt-to-collateral value ratio exceeds one without further foreign investment, then domestic banks and firms will go bankrupt. 
In a word, if the fear of the domestic country going bankrupt becomes prevalent among foreign investors, then it can turn into a self-fulfilling prophecy. ${ }^{23}$

Even when the economy is hit by a temporary adverse shock, in terms of trade for example, the vulnerability of the financial system can result in a crisis. Even a little doubt concerning the economy's capability for future debt service can make a foreign investor run to a domestic bank and recall the loan, which can easily trigger other investors' runs on all the other banks. Radelet and Sachs (1998), and Chang and Velasco (1998) among others explain the recent East Asian crises by this self-fulfilling bank run a la Diamond and Dybvig.

A myopic or a more cautious behavior of foreign investors can easily invite a financial crisis. We have assumed that foreign investors will lend money to domestic banks as long as the collateral lending condition is satisfied, just as domestic banks behave toward domestic firms. However, in the real world foreign investors are less tolerant and more cautious than domestic banks in evaluating the situation of the debtor economy because they do not hold collateral directly, nor do they have the loan guarantee, explicit or implicit, which domestic financial institutions obtain from the government. Consequently, foreign investors may have threshold levels lower than one, or different expected ratios in the collateral lending condition, which will make the economy further vulnerable to even smaller shocks. In the next section, we will discuss the above implications of banking and economic crises under financial liberalization.

\footnotetext{
${ }^{23}$ This self-fulfilling prophecy is further strengthened with an additional assumption that land price possesses a positive bubble term that will vanish as soon as foreign investors stop lending: if foreign investors stop lending, the land price will drop to such a level that the probability of violating the collateral lending condition becomes much higher.
} 


\section{Capital Market Liberalization}

In previous sections, we assume that foreign capital inflow is allowed only to compensate for the loss of the firm indirectly through bank financing. This section considers the impact of financial opening on prompting banking and economic crises. This consideration is important because capital market liberalization and consequent asset price boom and bust often preceded banking and economic crises in most of the countries having experienced recent economic crises (Kaminsky and Reinhart, 1996).

We assume that domestic firms and financial institutions are allowed to borrow foreign capital freely at the world interest rate $r^{f}$ as long as the collateral lending constraint is satisfied. The other assumptions are identical to those in the previous sections.

\subsection{Firm's Maximization}

The representative firm maximizes its expected discounted profit under financial liberalization as

(28) $\max E_{t}\left[\sum_{k=0}^{\infty} \frac{1}{\left(r^{f}\right)^{k}}\left\{(1+s) A_{t+k}\left(\dot{k}_{t+k}+k_{t+k}^{f}\right)+q_{t+k} \bar{h}-r^{f}\left(\dot{\circ}_{t+k}+k_{t+k}^{f}\right)-T_{t+k}\right\}\right]$

subject to satisfying the collateral lending constraint,

where $\stackrel{\circ}{k}_{t+k}$ indicates the amount of the equilibrium capital stock when the capital market is closed.

We assume that $A_{t}<r^{f}<(1+s) A_{t}$. Then, the firm's objective function implies that an additional unit of foreign capital increases the profit (hence, dividend) by $(1+s) A_{t}-r^{f}$. Thus, after the opening, the entrepreneur borrows additional foreign capital $\left(k_{t}^{f}\right)$ as much as the maximum allowed by the collateral lending constraint. However, this borrowing decreases the GNP by $r^{f}-A_{t}$, because we assume that the marginal productivity of capital is lower than the 
cost of foreign capital. ${ }^{24}$ The above maximization problem with a control variable $\left(\dot{k}_{t}+k_{t}^{f}\right)$, will produce the relationships identical to those in the previous sections with some exceptions as shown in the equations below.

Now, the government balanced budget implies

$$
s A_{t}\left(\stackrel{\circ}{k}_{t}+k_{t}^{f}\right)=T_{t}
$$

This also implies that the current account deficit is $s A_{t}\left(\dot{k}_{t}+k_{t}^{f}\right)=T_{t}$.

Considering that the lower borrowing cost and the additional foreign capital inflow caused by opening the capital market increase the profit by $\left[\left(A_{t}(1+s)-r^{f}\right)\left(\dot{k}_{t}+k_{t}^{f}\right)\right]$, the dividend will increase as

$$
d_{t}=q_{t} \bar{h}+\left[\left(A_{t}(1+s)-r^{f}\right)\left(k_{t}^{\circ}+k_{t}^{f}\right)\right]
$$

From the above relationships, the firm's profit after dividends will be

$$
\begin{aligned}
\pi_{t} & =-T_{t} \\
& =-s A_{t}\left(\dot{k}_{t}+k_{t}^{f}\right)
\end{aligned}
$$

Recall that the firm will compensate for this loss by borrowing foreign capital through the domestic bank. The firm will do business even while accumulating losses as long as the firm can continue to borrow from the bank.

\footnotetext{
${ }^{24}$ This assumption is necessary to make 'overinvestment' occur in this economy.
} 


\subsection{Household's Maximization}

The maximization becomes very complicated mainly because financial liberalization increases the consumer's disposable income from $A_{t}(1+s) \dot{k}_{t}$ to $A_{t}(1+s)\left(\dot{k}_{t}+k_{t}^{f}\right)-r^{f} k_{t}^{f}$, and because foreign capital flows into the economy until the collateral lending condition binds in each period.

To simplify the problem, we additionally assume that $A_{i}=A$, and that capital liberalization started from minus infinity time to get steady state implications. Then, we can easily posit that consumption, domestic capital and foreign capital grow at a rate of $\beta A(1+s)$ with the collateral lending condition binding in each period. This will be verified in the next subsection.

Thus, we will have the following modified relationships.

$$
\begin{aligned}
& \left(\stackrel{\circ}{k+k^{f}}\right)^{\prime}=\beta \cdot A \cdot(1+s)\left(\stackrel{\circ}{k}+k^{f}\right), \\
& c=(1-\beta)\left\{A(1+s)\left(\stackrel{\circ}{k}+k^{f}\right)-r^{f} k^{f}\right\} .
\end{aligned}
$$

The optimal growth rates of consumption and capital stock are identical to those in the case before capital market liberalization. And equation (17) implies that the housing rental cost will rise because financial market liberalization increases the household's income. Two economiesone with financial liberalization and one without- are compared in Table 2 in the Appendix. 


\subsection{Bank's Behavior and Implications}

Assuming that $A_{t}=A$, the price of one unit of real estate is calculated as

$$
\begin{aligned}
P_{h t}^{o} & =E_{t}\left[\sum_{j=0}^{\infty} \frac{q_{t+j}}{\left(r^{f}\right)^{j}}\right] \\
& =E_{t}\left[\sum_{j=0}^{\infty} \frac{\theta c_{t+j}}{\left(r^{f}\right)^{j} \bar{h}}\right] \\
& =\sum_{j=0}^{\infty} \frac{(\beta(1+s) A)^{j} \theta c_{t}}{\left(r^{f}\right)^{j} \bar{h}} \\
& =\frac{r^{f}}{r^{f}-\beta(1+s) A} \frac{\theta}{\bar{h}} c_{t}
\end{aligned}
$$

where we assume that $A<r^{f}<(1+s) A$ and that $r^{f}>\beta(1+s) A$.

Equation (34) implies that the capital market liberalization increases the real estate price through two channels: by lowering the discount rate from the higher domestic interest rate to the lower world interest rate, and by increasing the level of consumption.

Now, let us calculate the collateral lending condition. Using equations (31), and (34), and the fact that the foreign capital inflow to compensate for the current account deficit at time $t$ is $s A\left(\dot{k}_{t}+k_{t}^{f}\right)$, we can explicitly calculate the collateral lending condition. The expected ratio of the bank loan to collateral is less than one, starting from the time of minus infinity, as

$$
E_{t}\left[\frac{L_{t+1}}{P_{h t+1} \bar{h}}\right]=E_{t}\left[\frac{F_{t+1}+r^{f} F_{t}+r^{f^{2}} F_{t-2}+\ldots+r^{f^{t+i+1}} F_{-i}+\ldots}{P_{h t+1}^{o}}\right] \leq 1,
$$

where $F_{t}=s A\left(\dot{k}_{t}+k_{t}^{f}\right)$

Right after the financial opening, a huge amount of foreign capital will flow into the country up to the limit in which equation (35) binds. As a result, the real estate price will soar as stated above. This also greatly increases consumption, investment, and income level. This equilibrium will converge to the steady state in which domestic and foreign capital as well as 
income and real estate price increase at the constant growth rate of $\beta A(1+s)$. Equations (32) to (35) can easily verify this in that the growth rate of domestic and foreign capital does not violate these conditions in the steady state.

However, if $A_{t}$ changes over time as in the real world, then the magnitude of foreign capital inflow and outflow greatly fluctuates depending on the value of $A_{t}{ }^{25}$ Thus, the growth rates of income, consumption, and investment change as well because the foreign capital flows into the country continuously to the limit of the credit, which depends on the value of $A_{t}$, as (35) implies.

Thus, this model explains the observed empirical fact: capital market liberalization leads to huge foreign capital inflows, which in turn increases income, consumption, and asset prices. This asset bubble induces a boom in lending to risky projects. Sooner or later, the asset bubble bursts at the expense of the banking sector. Then, it drives foreign investors to panic and to withdraw their loans all at once. Subsequently, banking and economic crises follow. The model provides the causal links as follows: financial opening leads to a huge foreign capital inflow, because firms want to maximize their profit by employing cheaper foreign capital within the collateral lending constraint. Then, the lower world interest rate and the higher consumption, caused by the huge inflow of cheaper foreign capital, will hike the real estate prices up, encouraging more foreign capital to flow in again by lowering the debt-to-collateral value ratio. This process brings about a lending boom, increasing the real estate price, income, investment and consumption levels. This lending boom can accelerate the growth of income if it allows firms to speculate in more risky projects with a higher $s$. This will raise the real estate price even further. Then, finally the bubble bursts and economic crisis sets in.

If the debt-to-collateral value ratio was below the self-fulfilling prophecy range before capital market liberalization, then the liberalization can push the debt-to-collateral value ratio into the self-fulfilling prophecy range presented in Proposition $3 .^{26}$ Then, the self-fulfilling

\footnotetext{
${ }^{25}$ It is a very interesting fact that due to the credit constraints imposed by collateral lending conditions macroeconomic variables change considerably as productivity changes. See Kiyotaki and Moore (1997) for a model in which a dynamic interaction between credit limits and asset prices makes the effects of productivity shocks persist. ${ }^{26}$ Another crisis-triggering mechanism can occur as follows. As more foreign capital flows in, current account deficits and foreign debts increase as implied by equation (29). If the increase in foreign debt (particularly, shortterm) hits a triggering point of the minimum level of foreign reserves, then foreign investors will panic and make
} 
prophecy of banking and economic crises will occur. The crisis with capital market liberalization will be much more severe than the one without capital market liberalization, because the huge outflows of foreign capital make income, investment, consumption levels and real estate prices plummet more than in the pre-liberalization case.

\section{Relations to Other Literature}

Recent theoretical models on the Asian Crisis such as Krugman(1998), Schneider and Tornell (1998), Corsetti et al.(1998), and others are based on 'overinvestment' caused by the moral hazard behavior of firms and banks. Even though our model does not possess this feature, we can reinterpret our model perfectly within the context of moral hazard behavior.

The following posits a typical model of moral hazard behavior. In each period, firms will have a good or a bad productivity shock. Due to the implicit bailout subsidy of the government, banks virtually freely provide loans to firms with bad productivity shocks to make them liquid and solvent. But firms and banks regard these loans as a government subsidy, which does not have to be repaid. This mechanism induces overinvestment in risky projects, a fragile financial system, an asset bubble and bust, and finally a banking and economic crisis.

The moral hazard behavior incurs crises in the following process. The over-investment caused by the moral hazard will increase the government burden of the implicit bailout subsidy. The bank's bad loans are financed continuously by foreign capital over time. Then, when the foreign debt grows too large compared to the size of the total liquid assets of the economy, foreign investors start to doubt the government's ability to pay back foreign debt. At this point in time, they start to make sudden withdrawals of foreign capital, and thus provoke a banking and economic crisis.

Our model is observationally a complete equivalent to this kind of moral hazard model. In other words, ours can be reinterpreted as the moral hazard model without having to change any of the equations in the previous sections but only with a slightly different interpretation of equations and variables. The following reinterpretation will transform our model into the moral hazard one.

sudden withdrawals of their capital. In Corsetti et al. (1998), the triggering base is the minimum level of reserves. For the reinterpretation of the model as a moral hazard model as in Corsetti et al., refer to Section 5. 
Assume a continuum of firms indexed by $i \in[0,1]$. In each period, half of the firms, chosen randomly, will have a good productivity shock of $(1+s) A_{t}$, while the other half a bad shock of $(1-s) A_{t}$. Thus on the aggregate, the average productivity is certain with $A_{t}$. Assume also that banks will provide loans of the amount of $2 s A_{t}$ per one unit of capital to the lower productivity firms to compensate for their bad luck. At this point, firms and banks regard these bad loans as an implicit government bailout subsidy. These loans are financed by foreign capital which foreign investors provide as long as they consider them to be backed by government subsidy. Thus, at the aggregate level, all the firms behave as if they have the productivity shock of $(1+s) A_{t}$ at time $t$ as in our model. We further assume that a pair of one firm and one bank is owned by an identical set of shareholders and managers, for simplicity. And this pair owns the real estate.

Then, the variable $T_{t}$ in this newly reinterpreted economy equals the total amount of loans provided to all the firms with a bad productivity shock at time t. In other words, $T_{t}$ denotes the implicit bailout subsidy flow to bad-luck firms at time t. And the variable $L_{t}$ represents the total accumulated foreign debt by banks which foreign investors believe will be paid by the government as a bailout subsidy.

In this new reinterpreted economy, when foreign investors start to doubt the government's ability to pay back, and thus withdraw their lending, a banking and economic crisis will occur. Then, the mechanism of triggering a crisis in this new moral hazard economy is as follows.

Assume that if the ratio of debts to government's assets, including its foreign reserves, plus the bank's real estate asset increases above a certain triggering point, then foreign investors will panic and make a sudden withdrawal of their invested capital. This triggering mechanism is plausible and similar to that in Corsetti et al. (1998). If the ratio of the government assets to foreign debts remains constant, or if the government's assets are negligible, then the triggering point will be the ratio of the real estate value to the debt, as in our model. Thus, the reinterpretation of equations and variables can transform our original model into a moral hazard one, as in Krugman (1998), Schneider and Tornell (1998), and Corsetti et al. (1998). ${ }^{27}$

\footnotetext{
${ }^{27}$ Our model in the version of the moral hazard distinguishes itself from other models in the following aspects. The model in Corsetti et al. does not include the implications of asset bubble and bust. Even though Krugman, and
} 


\section{Conclusion}

This paper attempts to model the recent experience of East Asian economies characterized by high growth and sudden financial crisis.

The model describes an economy in which firms, subsidized by the government, are motivated to over-invest and banks recklessly lend money to the firms. The model shows that the high growth economy caused by high government subsidies becomes more vulnerable to adverse shocks and more likely to become hostage to bank and foreign exchange crises when foreign investors stop lending money to domestic banks. This paper also demonstrates that capital market liberalization augments the likelihood of an even more severe crisis, especially in a high growth economy.

The economic crisis presented in this paper has a feature similar to the self-fulfilling prophecy of a bank run. When foreign banks or foreign investors start to regard the economies as risky, then it will surely become risky. One foreign investor's run on a domestic bank can trigger other investors' run on banks. The bank run feature of the model implies that financial crises can be contagious among similar countries with high debts. Once foreign investors have experienced a crisis in one country, they will become more cautious in making investments in economies with similar financial systems. Further investigation into this self-fulfilling feature of financial crisis across the East Asian countries will be an important agenda for future research.

Schneider and Tornell focus on the mechanics of asset bubble and bust, their models do not have the features of a general equilibrium model as fully as ours do. 


\section{Reference}

Barro Robert, and Xavier Sala-I-Martin, Economic Growth, McGraw-Hill, Cambridge, MA.

Chang, Roberto and Andres Velasco, 1998, "Financial Crises in Emerging Markets: A Canonical Model," NBER working paper No.6606, June.

Corsetti, Giancarlo, Paolo Pesenti, and Nouriel Roubini, 1998, "Paper Tigers? A Preliminary Assessment of the Asian Crisis." Working paper, New York University.

Demirguc-Kunt Ash and Enrica Detragiache, 1997, "The Determinants of Banking Crises: Evidence from Developing and Developed Countries," IMF Working paper 97/106.

Diamond, D. and P.Dybvig, 1983, "Bank Runs, Deposit Insurance, and Liquidity," Journal of Political Economy, 91(3), pp.401-419.

International Monetary Fund, World Economic Outlook, Interim Assessment, December 1997.

Kaminsky, G. and C.M. Reinhart, 1996, "The Twin Crises: The Causes of Banking and Balance of Payments Problems," Working paper, Federal Reserve Board.

Kiyotaki Nobuhiro, and John Moore, 1997, "Credit Cycles," Journal of Political Economy, 105(2), pp.211-248.

Kornai, Janos, 1979, "Demand versus Resource Constrained Systems," Econometrica 47, pp.801-819.

Krugman, Paul, 1994, "The Myth of Asia's Miracle.” Foreign Affairs, pp.62-78.

Krugman, Paul, 1998, “What Happened to Asia?” mimeo., M.I.T.

Lee, J.-W., 1996, "Government Interventions and Productivity Growth," Journal of Economic Growth, vol. 1, pp. 391-414.

Radelet Steve and Jeffrey Sachs, 1998, "On the Onset of the East Asian Financial Crisis," development discussion paper, Harvard Institute for International Development.

Schneider Martin and Aaron Tornell, 1998, "Lending Booms and Asset Price Bubbles," Mimeo., Stanford University.

World Bank, 1998, East Asia: The Road to Recovery. 


\section{Appendix}

Table 1: Comparison between an Economy Characterized by Over-investment and a Normal Economy

\begin{tabular}{|l|c|c|}
\hline & Over-investing Economy & Normal Economy \\
\hline $\begin{array}{l}\text { Growth Rate of GNP } \\
\text { and Real Estate Prices }\end{array}$ & $\beta A_{t}(1+s)$ & $\beta A_{t}$ \\
\hline Consumption / GNP & $(1-\beta)(1+s)$ & $1-\beta$ \\
\hline Investment / GNP & $\beta(1+s)$ & $\beta$ \\
\hline Land Value / GNP & $\theta(1+s)$ & $\theta$ \\
\hline $\begin{array}{l}\text { Current Account Deficits/ } \\
\text { GNP }\end{array}$ & $s$ & 0 \\
\hline National Debt / GNP & Less than $\frac{s(1+s) \beta \underline{\underline{A}}}{(1+s) \beta \underline{\underline{A}}-r^{f}}$ & \\
\hline Interest Rates & $A_{t}(1+s)$ & $A_{t}$ \\
\hline
\end{tabular}


Table 2: Comparison between Two Economies- With and Without Capital Market Liberalization

\begin{tabular}{|c|c|c|}
\hline & No Liberalization & Liberalization \\
\hline GDP & $A_{t} \stackrel{\circ}{k}_{t}$ & $A_{t}\left(\stackrel{\circ}{k}_{t}+k_{t}^{f}\right)$ \\
\hline GNP & $A_{t} \stackrel{\circ}{k}_{t}$ & $A_{t}\left(\stackrel{\circ}{k}_{t}+k_{t}^{f}\right)-r^{f} k_{t}^{f}$ \\
\hline Current Account Deficit & $s A_{t} \stackrel{\circ}{k}_{t}$ & $s A_{t}\left(\dot{k}_{t}+k_{t}^{f}\right)$ \\
\hline Interest Rate & $(1+s) A_{t}$ & $r^{f}$ \\
\hline Growth Rate & $\beta(1+s) A_{t}$ & $\beta(1+s) A_{t}$ \\
\hline Real Estate Prices & $P_{h t}$ & $\begin{aligned} P_{h t}^{f}= & P_{h t} \frac{(1-\beta) r^{f}}{r^{f}-\beta(1+s) A} \times \\
& \frac{A(1+s)\left(k^{\circ}+k^{f}\right)-r^{f} k^{f}}{A(1+s) \stackrel{o}{k}}\end{aligned}$ \\
\hline
\end{tabular}

